\title{
Consumenten
}

\section{The New Consumer Deal}

\author{
Een gamechanger op het gebied van de afwikkeling van massaclaims?
}

Mr. dr. B. van Hattum*

De Europese Commissie (hierna: Commissie) heeft als onderdeel van een New Consumer Deal (hierna: de Deal) een richtlijnvoorstel gepubliceerd waar de invoering van een groepsvordering in de Europese Unie wordt voorgesteld om te kunnen garanderen dat de Europese consument ten volle van zijn rechten als EUburger kan genieten. De Commissie kiest voor het toebedelen van de groepsvordering aan een met specifieke voorwaarden omklede entiteit. In de praktijk zal dit neerkomen op het toekennen van een groepsvordering aan een consumentenvereniging, een voor een specifieke vorm van massaschadeafwikkeling opgerichte en door de overheid ondersteunde stichting en/of een toezichthouder. In hoeverre is deze keuze van de Commissie een gamechanger in het speelveld van massaschadeafwikkeling en zal de invoering van een groepsvordering bijdragen aan het door de commissie beoogde doel van het waarborgen van de rechten van de EU-burger?

Voorstel betreffende representatieve vorderingen ter bescherming van de collectieve belangen van consumenten en tot intrekking van Richtlijn 2009/22/EG. Brussels 11 april 2018 COM(2018)184 final 2018/0089 (COD).

\section{Inleiding}

Op 11 april 2018 heeft de Commissie een nieuwe Deal voor de consument gepresenteerd om te kunnen garanderen dat deze in Europa ten volle van zijn rechten als EU-burger kan genieten. ${ }^{1}$ Als onderdeel van deze nieuwe aanpak is een voorstel voor een richtlijn vastgesteld die een groepsvordering in de hele EU mogelijk moet maken. Deze richtlijn dient bij te dragen aan het versterken van de rechtspositie van de Europese consument

Mr. dr. B. (Bonne) van Hattum is verbonden als wetenschapper aan de Universiteit van Amsterdam en als beleidsmedewerker bij de Autoriteit Financiële Markten (AFM). Zij schrijft dit artikel op persoonlijke titel.

1. Zie <http://europa.eu/rapid/press-release_IP-18-3041_en.htm> (laatst gecontroleerd op 24 april 2018). via het vergroten van zijn verhaalsmogelijkheden met betrekking tot geleden schade. De andere helft van de Deal beoogt de consument adequater te beschermen voorafgaande aan het ontstaan van schade. ${ }^{2} \mathrm{Ik}$ dit artikel beperk ik mij tot de introductie van een Europese groepsvordering.

De Commissie kiest voor het toekennen van een groepsvordering aan een entiteit die de doelstellingen van de richtlijnen die de gehele Deal omvatten kan waarborgen. De betreffende entiteit mag daarbij ook geen winstoogmerk hebben (zie art. 1 richtlijnvoorstel met betrekking tot de invoering van groepsvordering in Europa, hierna: Voorstel). ${ }^{3}$ In de praktijk kan het gaan om verschillende instanties, bijvoorbeeld een erkende consumentenvereniging zoals de Consumentenbond, een voor een specifieke vorm van massaschade opgerichte en door de overheid ondersteunde stichting, een Ombudsman en/of een nationale toezichthouder zoals de Autoriteit Consument en Markt (ACM) of de Autoriteit Financiële Markten (AFM). De door de Commissie beoogde entiteit dient goed in staat te worden gesteld om zowel tijdelijke als definitieve maatregelen te kunnen treffen voor de consument om schadelijke handelspraktijken te kunnen voorkomen en indien al gaande ook te kunnen stoppen. ${ }^{4}$

Het Voorstel verplicht de lidstaten verder een entiteit aan te wijzen die compensatie voor geleden schade kan realiseren via het opleggen van herstelacties, vervanging, prijsreductie, teruggave van gemaakte kosten en het betalen van in geld uitgedrukte compensatie voor geleden schade. ${ }^{5}$ Het staat de lidstaten vrij om te bepalen of deze acties in het publiek- of in het privaatrecht worden verankerd. ${ }^{6}$

Door de specifieke omschrijving van beoogde bevoegdheden ligt het toekennen van een rol voor een toezicht-

2. Dit onderdeel van de New Consumer Deal zal in een volgend nummer van NtEr worden besproken.

$\operatorname{COM}(2018) 184$ final, d.d. 11 april 2018.

Voorstel, p. 3.

Art. 6 lid 1 Voorstel.

Punt 12 Voorstel, p. 20. 
houder bij het uitoefenen van al deze acties voor de hand. Maar er kan in Nederland ook worden gedacht aan een wisselwerking en daarmee een verdeling van bevoegdheden tussen bijvoorbeeld de Consumentenbond, een Ombudsman en/of een door de overheid opgetuigde claimstichting voor het beslechten van een speciale massaclaim ${ }^{7}$ en een toezichthouder.

In dit artikel beantwoord ik op basis van bovenstaande de vraag in hoeverre het toekennen van een rol op het gebied van massaclaimafwikkeling ${ }^{8}$ voor een consumentenorganisatie en/of een toezichthouder een gamechanger is voor het speelveld waarbinnen nu massaclaims in Europa en specifiek in Nederland worden afgewikkeld. Hoe realistisch is het ten slotte dat met de invoering van een Europese groepsvordering het door de commissie beoogde doel van het waarborgen van de rechten van de EU-burger, beter dan in het verleden het geval was, zal worden behaald?

\section{Aanleiding voor de totstandkoming van een}

\section{Europese groepsvordering}

Het versterken van de rechtspositie van de consument is al sinds 1975 een speerpunt van de Commissie. ${ }^{9}$ Een van de actiepunten met betrekking tot dit speerpunt is het verlagen van de drempel voor de toegang tot het recht voor een gewone consument om zijn schade op een (potentiële) schadeveroorzaker te kunnen verhalen, naast het versterken van beschermingsmaatregelen zoals toezicht om schade voor een consument te voorkomen. ${ }^{10}$ Voor het verlagen van de drempel voor de toegang tot het recht, in de vorm van het mogelijk maken van collectief verhaal in de Europese Unie, ${ }^{11}$ zijn al vele acties

7. Onder een massaclaim versta ik een claim die is gericht op het vergoeden van massaschade. Voor dit begrip verwijs ik naar I.N. Tzankova, Toegang tot het recht bij massaschade (diss. Tilburg), Tilburg 2007, p. 1-2.

8. Onder massaclaimafwikkeling versta ik zowel individuele als collectieve claimafwikkeling via allerlei vormen van geschilbeslechting (via de rechterlijke organisatie, een Ombudsman, een toezichthouder, een Commissie van Wijzen of andere alternatieve vormen van geschilbeslechting). Individuele claimafwikkeling betreft de afwikkeling van claims die in potentie via precedentwerking kunnen leiden tot een massaclaim al dan niet via aansturing of ondersteuning van een claimorganisatie. Of het betreft claims die overblijven om af te wikkelen in geval van het gebruikmaken van een algemeen verbindend verklaarde schikking. Dit kan in Nederland via gebruikmaking van een opt-out-mogelijkheid ex art. 7:908 lid 2 BW bij de WCAM-procedure (Wet Collectieve Afwikkeling Massaschade, Wet van 27 juli 2005, Stb. 2005, 340 en 380). Collectieve claimafwikkeling betreft in Nederland de afwikkeling van zorgplichtclaims via gebruikmaking van een collectieve-actieprocedure ex art. 3:305a-c BW en/of via art. 7:907 BW e.v. inclusief art. 1013-1018 Rv.

9. J. Valant, 'Consumer Protection. Policy Overview', i.o. van de Europese Commissie 2015, p. 1.

10. <http://ec.europa.eu/newsroom/just/item-detail.cfm?item_id= 620435> (laatst gecontroleerd op 8 mei 2018).

11. Opties om de drempel voor individuele toegang tot het recht voor een consument te verlagen zijn in het verleden ook op Europees niveau doorgevoerd. Zie hiervoor in eerste instantie Richtlijn 2013/11/EU van het Europees Parlement en de Raad van 21 mei 2013 betreffende alternatieve beslechting van consumentengeschillen (ADR-richtlijn). De mechanismen van het Unierecht waarvan individuele consumenten gebruik kunnen maken om hun rechten te doen gelden, worden ook uiteengezet in andere instrumenten, zoals Verordening (EU) 2015/2421 van het Europees Parlement en de Raad van 16 december 2015 tot wijziging van Verordening (EG) nr. 861/2007 tot vaststelling van een op Europees niveau ondernomen, ${ }^{12}$ met name op het gebied van het mededingingsrecht. ${ }^{13}$ Alle genoemde acties zijn onderbouwd via diverse (probleem)analyses gebaseerd op in opdracht van de Commissie uitgevoerde onderzoeken. ${ }^{14}$

De exacte aanleiding voor de totstandkoming van het voorstel voor de invoering van een Europese groepsvordering is artikel 30 van de Consumentenrichtlijn dat een evaluatie van deze richtlijn na een aantal jaren inhoudt. ${ }^{15}$ De Consumentenrichtlijn beoogt consumenten adequaat te beschermen voor schade opgelopen door de aanschaf van gebrekkige producten en dienstverlening. Ook beoogt de Consumentenrichtlijn de Europese retailmarkt op een hoger plan te tillen door grensoverschrijdende dienstverlening via allerlei maatregelen te bevorderen. De evaluatie is tegelijkertijd met een grotere REFIT-geschiktheidscheck (check op een gezonde en resultaatgerichte regelgeving) ${ }^{16}$ van het consumentenen marketingrecht van de EU uitgevoerd.

Europese procedure voor geringe vorderingen en Verordening (EG) nr. $1896 / 2006$ tot invoering van een Europese betalingsbevelprocedure, en Richtlijn 2008/52/EG van het Europees Parlement en de Raad van 21 mei 2008 betreffende bepaalde aspecten van bemiddeling/mediation in burgerlijke en handelszaken. Zie Voorstel, p. 6.

12. Zo zijn er twee Groenboeken en een Witboek gepubliceerd in 2005 en

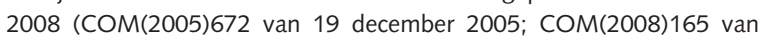

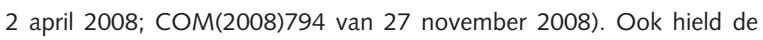
Commissie een openbare raadpleging in 2011 (COM(2010)135 final van 31 maart 2010). Op 2 februari 2012 nam het Europees Parlement de resolutie aan, waarin het de wens uitdrukte dat eventuele voorstellen voor collectief verhaal de vorm van een horizontaal kader zouden krijgen, met inbegrip van een reeks gemeenschappelijke beginselen, dat binnen de EU via het collectief verhaal een uniforme toegang tot de rechter waarborgt en specifiek, maar niet uitsluitend, gericht is op schendingen van consumentenrechten 2011/2089(INI). In 2013 zijn er aanbevelingen gepubliceerd door de Commissie hoe om te gaan met collectief verhaal in Europa COM(2013)401 final. Deze aanbevelingen zijn uiteindelijk aangescherpt en in een richtlijnvoorstel gepubliceerd op 11 april $2018 \operatorname{COM}(2018) 184$ final.

13. Zie bijvoorbeeld: Impact Assessment Report accompanying the proposal for a Directive of the European Parliament and the Council on certain rules governing actions for damages under national law for infringements of the competition law provisions of the Member States and the European Union, SWD (2013) 203 final, nr. 52; Richtlijn 2014/104/EU; C.A.N.M.Y. Cauffman, 'De Richtlijn betreffende schadevorderingen wegens inbreuken op het mededingingsrecht', SEW 2015-3 en R. Meijer, 'Follow-on schadeclaims wegens schending van het mededingsingsrecht: van law in the books naar law in action, Contracteren 2018-1. In Europese massaclaim wet- en regelgeving is voornamelijk een rol voor een toezichthouder weggelegd die bestaat uit het aanjagen van private afwikkeling van massaclaims via het publiceren van feitenrapporten over mededingingsinbreuken. Zie hiervoor o.a. Meijer 2018.

14. Zie hiervoor o.a. J. Stuyck e.a., 'An analysis and evaluation of alternative means of consumer redress other than redress through ordinary judicial proceedings', Final Report i.o.v. de Europese Commissie, Leuven 2007; Civic Consulting, 'Evaluation of the effectiveness and efficiency of collective redress mechanisms in the European Union', Final Report i.o.v. European Commission - DG SANCO 2007.

15. Richtlijn 2011/83 / EU van 25 oktober 2011 betreffende consumentenrechten (CRD). Volgens art. 30 van de richtlijn dient de EC uiterlijk 13 december 2016 bij het Europees Parlement en de Raad een verslag in over de toepassing van de richtlijn. Dit verslag omvat met name een evaluatie van de bepalingen van deze richtlijn die betrekking hebben op digitale inhoud, inclusief het herroepingsrecht.

16. Zie <https://ec.europa.eu/info/law/law-making-process/evaluating-and -improving-existing-laws/refit-making-eu-law-simpler-and-less-costly_ nl> (laatst gecontroleerd op 20 april 2018). 
Hoewel volgens de Commissie de EU-regels betreffende consumentenbescherming al bij de strengste ter wereld horen, blijkt uit de evaluatie dat de Consumentenrichtlijn op een aantal punten nog dient te worden aangescherpt. De aanscherping moet gebeuren om de beoogde doelstelling van de richtlijn adequater dan in het verleden mogelijk was te kunnen behalen. Een van de voorgestelde aanscherpingen van het consumentenbeschermingsbeleid betreft de invoering van een groepsvordering in alle lidstaten van de Europese Unie. ${ }^{17}$

De directe aanleiding hiervoor is vooral Dieselgate ofwel het Volkswagenschandaal. ${ }^{18}$ Uit de evaluatie bleek dat de door de Dieselgate ontstane schade te moeilijk was om op de veroorzakers ervan te kunnen verhalen. Een verbreding van de toegang tot het recht voor consumenten via de invoering van een Europese variant op de Amerikaanse class action procedure ${ }^{19}$ of via de invoering van een groepsvorderingsmogelijkheid ziet de commissie als een oplossing. Door de invoering van een Europese groepsvorderingsmogelijkheid kunnen hiervoor bevoegde instanties namens consumenten groepsvorderingen indienen en andere maatregelen treffen om geleden schade door consumenten te verzachten of geheel te herstellen.

\section{De inhoud van het voorstel}

- Doelstelling moet behaald morden door een daarvoor gekmalificeerde entiteit

De inhoud van de Deal, met betrekking tot het onderdeel groepsvordering, beoogt het toebedelen van een groepsvordering aan een daarvoor bevoegde entiteit. Deze entiteit moet voldoen aan een drietal voorwaarden: 20

1. voldoen aan alle bepalingen van het wettelijk kader inclusief bestaande gedragscodes van de betreffende lidstaat;

2. een legitiem belang hebben om de doelstellingen van alle in de New Consumer Deal besloten richtlijnen na te leven;

3. geen winstoogmerk hebben.

\section{- Reikmijdte}

Een bevoegde entiteit mag optreden wanneer er sprake is van (mogelijke) inbreuken op het gebied van het consumentenbeschermingsrecht. Het gaat dus zowel om acties die tot een inbreuk en daarmee massaschade kunnen leiden, als acties door een onderneming die al een inbreuk op het recht vormen. ${ }^{21}$ De reikwijdte van het terrein waarop een bevoegde entiteit dient te kunnen optreden is neergelegd in Annex 1 bij het Voorstel en wijd verspreid. Van privacy-schendingen tot zorgplichtschendingen op de financiële markten, van misleidingen

17. De overige aanscherpingen worden in een volgend nummer van NtEr besproken.

18. Lees hierover o.a. <www.nu.nl/volkswagen-schandaal/4131514/moetweten-dieselschandaal-van-volkswagen.html> (laatst gecontroleerd op 24 april 2018).

19. Federal Rule of Civil Procedure 23.

20. Art. 4 lid 1 Voorstel

21. Art. 5 lid 2 en lid 3 Voorstel. op het gebied van energiecontracten tot milieuvervuiling. ${ }^{22}$

\section{- Bevoegdheden}

De bevoegdheden die dienen te worden toebedeeld aan de betreffende entiteit liggen zoals hiervoor omschreven zowel op het terrein van het voorkomen als op het terrein van het afwikkelen van massaclaims. Dit betreft concreet bevoegdheden zoals het kunnen geven van een dwingende opdracht om een inbreuk te stoppen of te verbieden, om te bevestigen dat er een inbreuk heeft plaatsgevonden en om verhaal te halen op de inbreukpleger in de vorm van compensaties, herstelmaatregelen en prijsreducties. $^{23}$

\section{- $\quad$ Scheiding uitoefening bevoegdheden per categorie} massaschade

De Commissie heeft een scheiding gemaakt tussen de mogelijkheden om compensatie of schadevergoeding te vorderen in groepsverband voor strooischade versus 'gewone' massaschadegevallen (substantiële massaschade). ${ }^{24}$ Het proces van afwikkeling van zowel strooischadegevallen als de twee vormen van substantiële massaschade (gefixeerde en sluipende) is in het Voorstel verschillend.

De commissie beoogt om strooischade slechts via een publiekrechtelijk vormgegeven fonds tot uitkering aan gedupeerden mogelijk te maken. ${ }^{25}$ Gefixeerde vormen van substantiële massaschadegevallen kunnen straks via een beschikking (redress order) direct in compensatie voor geleden schade worden verdisconteerd. ${ }^{26}$ Sluipende vormen van substantiële massaschadegevallen zijn complexer van aard en hebben daarom volgens de Commissie een meer individuele benadering voor het bepalen van schade nodig. Hierdoor kan er wel via een groepsvordering aansprakelijkheid van een veroorzaker van de schade worden vastgesteld, maar dient schadevergoeding individueel te worden verhaald op de veroorzaker via het volgen van een daarvoor passende juridische procedure. ${ }^{27}$

22. Punt 6 Voorstel, p. 19

23. Punt 1 Voorstel, p. 18.

24. Ex art. 6 Voorstel. Onder strooischade wordt schade verstaan waarbij de individuele schade zo gering is, dat het op grond van een kostenbatenanalyse niet loont die schade individueel te verhalen, maar waarbij de collectieve schade gecumuleerd wel een aanzienlijk belang vertegenwoordigt. De 'gewone' vorm van massaschade betreft substantiële schade waarbij het individueel financieel belang geen individuele actie rechtvaardigt. De substantiële massaschadegevallen kunnen weer worden opgesplitst in sluipende en gefixeerde gevallen. Sluipende vormen zijn complex van aard. Ze zijn vaak niet het resultaat van één gebeurtenis, maar van een reeks van gebeurtenissen, waarbij de schade pas na verloop van tijd ontstaat of manifest wordt. De gefixeerde gevallen zijn minder complex van aard. Hun oorzaak is gemakkelijker dan bij sluipende gevallen vast te stellen. Ook is de groep gedupeerden gemakkelijker te identificeren bijvoorbeeld via een klantenbestand van een onderneming. Zie voor nadere toelichting op de in deze voetnoot gehanteerde begrippen met name: W.H. van Boom e.a., Strooischade, rapport EZ uitgevoerd door Pels Rijcken 2009, p. 10; Tzankova 2007, p. 15-16; het begrip 'sluipende massaschade' is ontleend aan J. Spier, Sluipende schade (Oratie Tilburg), Deventer: Kluwer 1990.

25. Punt 21 Voorstel, p. 22.

26. Art. 6 lid 1 Voorstel.

27. Art. 6 lid 2 en lid 3 Voorstel. 
- Vrijheid implementatie bevoegdheden in publieken/of privaatrechtelijk mettelijk kader

Het Voorstel laat het lidstaten vrij om te bepalen in welk wettelijk kader ze de bevoegdheden met bijbehorende procedures wensen te plaatsen. Dit kan volgens de Commissie zowel in het publiekrecht als in het privaatrecht zijn. ${ }^{28}$ Daarom kan ervoor worden gekozen om een toezichthouder een aanwijzingsbevoegdheid toe te kennen op het gebied van bijvoorbeeld het afdwingen van compensatie aan gedupeerde klanten van een onder toezicht staande instelling die een inbreuk heeft gepleegd op het bijbehorende wettelijke kader. Ook kan ervoor worden gekozen om een toezichthouder te laten optreden als een claimorganisatie ${ }^{29}$ zoals de ACM dat nu in Nederland al kan. ${ }^{30}$ Maar er kan (eventueel tegelijkertijd met de publiekrechtelijk toebedeelde bevoegdheden aan een toezichthouder) ook voor worden gekozen om een consumentenvereniging of speciaal opgerichte stichting de mogelijkheid te geven om via een privaatrechtelijke procedure deze acties uit te laten oefenen.

- Opt-out in plaats van opt-in

Verder dienen de lidstaten bij de implementatie van de inhoud van het voorstel de rechten van een EU-burger met betrekking tot de toegang tot het recht en het behoud van eigendomsrechten te waarborgen. In dit kader heeft de Commissie gekozen voor het toestaan van een opt-outmogelijkheid voor gedupeerde klanten die vallen onder een bepaalde groepsvordering en het mogen betwisten van de inhoud van een groepsvordering. ${ }^{31}$ Er lijkt bewust te zijn gekozen voor het mogelijk maken van een opt-outmodel in plaats van het optinmodel. De keuze voor een opt-outmodel heeft de Commissie waarschijnlijk gebaseerd op het feit dat de uitvoering van een groepsvorderingsactie voor een bevoegde entiteit in de praktijk hierdoor gemakkelijker is. ${ }^{32}$ Finale beslechting zit ook in het Voorstel verdisconteerd. Maar gezien de keuze voor het opt-outmodel en niet voor een vorm van een Amerikaanse mandatory class action, ${ }^{33}$ is daarvan in de praktijk straks echt sprake wanneer er slechts een te verwaarlozen groep opt-outers

28. Punt 12 Voorstel, p. 20.

29. Onder een claimorganisatie versta ik een organisatie die namens een groep gedupeerde klanten van een onderneming kan gaan onderhandelen met een of meer potentiële schadeveroorzakende ondernemingen en/of namens een collectief een juridische procedure kan gaan starten om schade voor de achterban te gaan verhalen.

30. Art. 3:305b BW en art. 2.6 Wet handhaving consumentenrecht (Whc).

31. Art. 5 lid 2, art. 6 lid 4 en art. 8 lid 6 Voorstel.

32. Voor het praktisch mogelijk maken van de gevraagde groepsvorderingsacties door een bevoegde entiteit, is het adequater om niet alle individueel betrokken consumenten van tevoren te moeten identificeren. Hetzelfde geldt voor het van tevoren volledig vaststellen van aansprakelijkheden. Ook wijst de praktijk uit dat consumenten zich actief (in geval van een opt-inmodel) lastig blijken aan te sluiten bij een belangenbehartiger. Er moet door een bevoegde entiteit conform het Voorstel worden opgetreden wanneer met een grote mate van waarschijnlijkheid door deze entiteit kan worden betoogd dat er inbreuken hebben plaatsgevonden of zullen gaan plaatsvinden die de rechten van consumenten binnen de EU (zullen) schaden ex art. 5 lid 2 Voorstel. Dit betekent dus niet alleen handhavend optreden op basis van al schadelijk gedrag maar ook wanneer dit schadelijke gedrag op het punt staat te kunnen gaan plaatsvinden.

33. Rule 23(b)(1)(B). overblijft na een getroffen en door een rechter goedgekeurde schikking of uit de procedure voortvloeiend gerechtelijk oordeel.

\section{- Financieringsmogelijkheden}

In het Voorstel wordt ook gesproken over welke vorm van financiering op welke wijze is toegestaan om een groepsvordering te kunnen uitvoeren. In het kort komt dit neer op transparantie over wie een groepsvordering financiert en hoe. Het is daarbij verboden om een derde geldstroom financieringsmaatschappij (third party funder) invloed te laten uitoefenen op de strategie en daarbij te maken besluiten om een groepsvordering aan te gaan en om schikkingen te treffen. Verder is het verboden om een entiteit te financieren die een concurrent van de financieringsmaatschappij wil gaan aanklagen of een entiteit die tegen een organisatie een groepsvordering wil starten waarvan de financieringsmaatschappij afhankelijk is. ${ }^{34}$

\section{- Minimumharmonisatie}

Alle hierboven beschreven maatregelen dienen door de lidstaten te worden overgenomen op basis van minimumharmonisatie. ${ }^{35}$ Dit betekent dat moet worden uitgegaan van de aangegeven beschermingslat met bijbehorende opties. Deze vormen een ondergrens. Strengere regels om de beoogde beschermingslat te behalen mogen worden toegepast, maar afzwakking van de beoogde mate van bescherming mag niet plaatsvinden. Dit zal impact hebben op het wettelijk kader en de bijbehorende praktijk met betrekking tot de afwikkeling van massaclaims in vele lidstaten van de Europese Unie waaronder ook Nederland. Maar het Voorstel kan niet bestaande (rechts)middelen van consumenten aantasten. ${ }^{36}$ Ook doet het Voorstel geen afbreuk aan de al bestaande weten regelgeving op het gebied van het internationaal privaatrecht specifiek met betrekking tot rechterlijke bevoegdheden en toegankelijkheidscriteria. ${ }^{37}$

Analyse en impact op het Nederlandse model voor de afwikkeling van massaclaims

- Het Nederlandse mettelijk kader voor de afwikkeling van massaclaims

De afwikkeling van massaclaims in Nederland en vele andere lidstaten in Europa is gebaseerd op het beginsel van contractsvrijheid en daarmee ook van partijautonomie. ${ }^{38}$ Efficiëntie en effectiviteit zijn de belangrijkste drijfveren van de wetgever waarop aanpassingen in het bijbehorende wettelijk kader zijn doorgevoerd. ${ }^{39}$ Het wettelijk kader voor de afwikkeling van massaclaims in

34. Art. 7 Voorstel.

35. Art. 1 lid 2 Voorstel.

36. Art. 2 lid 2 Voorstel.

37. Art. 2 lid 3 Voorstel.

38. A. Wardhaugh, 'Bogeyman, lunatics and fanatics: collective actions and the private enforcement of European competition law', Legal Studies 2014, afl. 1, p. 15.

39. B. van Hattum, De afwikkeling van zorgplichtclaims. Een onderzoek naar het adequater oplossen van affaires rondom retail-producten en dienstverlening op de financiële markten (diss. Amsterdam UvA), Den Haag: Boom juridisch 2017, p. 94. 
Nederland is daarom voornamelijk in het Burgerlijk Wetboek en het Wetboek van Burgerlijke Rechtsvordering weergegeven en daarmee privaatrechtelijk van aard. Voor alle vormen van massaschade geldt de collectieveactiemogelijkheid ex artikel 3:305a-c BW en de algemeenverbindendverklaringsmogelijkheid van een schikking ex artikel 7:907-7:910 BW en artikel 1013-1018 Rv (Wet Collectieve Afwikkeling Massaschade of WCAMprocedure).

Een claimorganisatie kan beide mogelijkheden aanwenden om schade namens een achterban op een potentiële schadeveroorzaker te verhalen. Om als claimorganisatie de betreffende procedures te mogen bewandelen moet deze aan verschillende geschiktheidsvereisten voldoen. Deze vereisten zijn neergelegd in de toegankelijkheidsvereisten behorende bij de betreffende procedures en in zelfregulering. ${ }^{40}$

Het Nederlandse wettelijk kader voor de afwikkeling van massaclaims is de laatste jaren geëvalueerd. Er is recent een wetsvoorstel aan de Tweede Kamer voorgelegd waarin wijzigingen voor een effectievere en efficiëntere afwikkeling zijn opgenomen. ${ }^{41}$ De wijzigingen die in het wetsvoorstel zijn opgenomen zijn onder andere gebaseerd op via wetenschappelijk onderzoek gevonden knelpunten in het Nederlandse afwikkelingssysteem van massaclaims. ${ }^{42}$ Deze knelpunten komen grofweg neer op het gemis van een afwikkelingssysteem dat een snelle, gecontroleerde en met een duurzaam (finaal) resultaat, voor een (dreigend of reeds bestaand) massaclaimgeschil kan waarborgen. ${ }^{43}$ Het wetsvoorstel is ten tijde van het schrijven van dit artikel nog niet door het Nederlandse parlement aangenomen. ${ }^{44}$

40. Art. 3:305a lid 1 en lid 2 BW inclusief art. 7:907 lid 1 BW en A.H. van Delden e.a., Claimcode, Den Haag: 2011

41. Kamerstukken // 2016/17, 34608, 2.

42. Zie hiervoor met name: Tzankova 2007; B. van Hattum, 'De verankering van een generieke zorgplicht in de Wet op het financieel toezicht', in: M.L. Hendrikse en J.G.J. Rinkes (red.), Naar een doorlopende generieke zorgplicht voor verzekeraars en verzekeringstussenpersonen? (ACIS-serie, deel 10), Zutphen: Paris 2012, p. 19-36; B. van Hattum, Handreiking voor de afwikkeling van massaclaims op de financiële markten. Mogelijkheden voor het reduceren van effecten van aanhoudend wantrouwen en instabiliteit op de financiële markten veroorzaakt door massaclaims: analyse en aanbevelingen, Den Haag: Boom Juridische uitgevers 2014; C.J.M. van Doorn, Belangen van benadeelden bij een collectieve afwikkeling van schade: een kwalitatief onderzoek naar de behoeften, verwachtingen en ervaringen van DSB-gedupeerden, Tilburg: Universiteit van Tilburg, TISCO 2015; E. Bauw en T.E. van der Linden, 'Claimorganisaties tussen wildgroei en regulering', TOP 2016/564 (Sdu online); E. Bauw en S. Voet, 'Van stok achter de deur tot keurslijf? Een verkenning van het wetsvoorstel tot invoering van een collectieve schadevergoedingsactie', NJB 2017, afl. 4, p. 240-247 en Van Hattum 2017.

43. Van Hattum 2017, p. 95.

44. De behandelingen van het wetsvoorstel door de Tweede Kamer staan gepland voor eind juni 2018. Zie hiervoor: <www.tweedekamer.nl/ debat_en_vergadering/plenaire_vergaderingen/details/activiteit?id= 2018A02395> (laatst gecontroleerd op 28 mei 2018).

\section{De keuze van de Commissie voor nadere invulling van een Europees afwikkelingssysteem voor massaclaims}

\author{
Een compromis tussen al aanwezige \\ afwikkelingssystemen
}

De in Nederlands onderzoek genoemde knelpunten voor in eerste instantie het afwikkelingsysteem van Nederlandse zorgplichtclaims, lijken overeen te komen met de in het Voorstel genoemde redenen voor aanpassing van het Europese afwikkelingssysteem. ${ }^{45}$ Daarin opgenomen anpassingen in het afwikkelingssysteem overigens globaal ook. ${ }^{46}$ De Commissie is in haar zoektocht naar passende aanpassingen in het afwikkelingssysteem duidelijk op zoek gegaan naar een compromis tussen al in sommige Europese lidstaten aanwezige systemen. ${ }^{47}$

\section{De verankering van het algemeen belang in een massaclaim}

De keuze van de Commissie voor de introductie van een publiekrechtelijke mogelijkheid om massaclaims af te kunnen wikkelen is niet onverwacht. ${ }^{48}$ Deze past binnen de vernieuwende inzichten die in de wetenschap en de praktijk van afwikkeling zijn opgedaan met betrekking tot gebreken in de afwikkelingssystemen van massaclaims in diverse landen waaronder de Verenigde Staten en Nederland. ${ }^{49}$ Een belangrijk gebrek is namelijk de waarborg van het algemeen belang bij de afwikkeling van massaclaims. ${ }^{50}$ Zeker op het gebied van de schending van consumentenbelangen is de waarborg van een dergelijk belang niet te verwaarlozen. Bij privaatrechtelijke afwikkeling waarbij advocatenkantoren vaak een grote rol spelen, kan gezien de beginselen van het privaat- en het procesrecht het algemeen belang zeer lastig in een eindresultaat worden verdisconteerd. Zo staat

45. Zie het Explanatory Memorandum behorende bij het voorstel.

46. Van Hattum 2017, hfdst. 8.

47. Zie voor een overzicht van diverse bevoegdheden van toezichthouders en andere publiekrechtelijk vormgegeven entiteiten op het gebied van claims: E. Terryn en P. Verbiest, 'De herziene CPC-verordening als oplossing voor grensoverschrijdend consumentenleed?', Tijdschrift voor Consumentenrecht en handelspraktijken 2018-1, p. 7.

48. De Commissie heeft in haar aanbevelingen in punt 6 over de Europese massaclaimafwikkeling in 2013 al gewezen op het feit dat zij het als een van de kerntaken van publieke handhaving ziet om schendingen van aan het EU-recht ontleende rechten te voorkomen en te bestraffen. De mogelijkheid voor particulieren om vorderingen in te stellen op basis van schendingen van die rechten, vormt een aanvulling op de publieke handhaving. Wanneer deze aanbeveling verwijst naar een schending van aan het EU-recht ontleende rechten, vallen daaronder alle situaties waarin de schending van op EU-niveau vastgestelde voorschriften schade heeft veroorzaakt of dreigt te veroorzaken aan natuurlijke personen en rechtspersonen (Aanbeveling 2013/396/EU).

49. P.L. Murray, Class Actions in the United States of America, Conference by Gesellschaft für Rechtsvergleichung, Basel 2017; Van Hattum 2017; J. van de Poel, 'Bij afwikkelen van massaschade wel degelijk rol weggelegd voor AFM', Het Financieele Dagblad 7 september 2017, <www.fd. $\mathrm{nl}>$ (laatst gecontroleerd op 24 april 2018).

50. Van Hattum 2017, par. 5.2.4.4; par. 6.5.1 en par. 6.5.4.1. 
daarin namelijk individuele afwikkeling op basis van alle omstandigheden van het geval voorop en dient er recht te worden gesproken op basis van wat partijen aandragen. Een derde belang mag een rechter dus niet ambtshalve meenemen in een eindoordeel. ${ }^{51}$

Maar het eindresultaat van bijvoorbeeld de afwikkeling van Dieselgate heeft effect op derden zoals een werknemer van Volkswagen, omdat deze zijn baan kan kwijtraken bij de uitbetaling van de betreffende claims. Ook kan het eindresultaat van de beslechting van de Woekerpolisaffaire impact hebben op de situatie van een klant van een verzekeraar die nooit een beleggingsverzekering heeft afgesloten. Zijn premie kan worden verhoogd om de kosten voor uitkering van schadecompensatie te verdisconteren. Ook kan de betreffende organisatie om het hoofd boven water te kunnen blijven houden worden gedwongen om bepaalde delen van de organisatie af te stoten of juist te moeten fuseren. Ook deze kosten kunnen op de 'gezonde klant' van een onderneming worden afgewenteld. De belastingbetaler kan ten slotte ook nog worden geraakt omdat een bepaalde onderneming gedupeerde klanten gedwongen moet compenseren wanneer ze niet in staat blijkt te zijn om aan prudentiële vereisten te kunnen voldoen. Tijdens de crisis heeft de overheid in Nederland vele banken en verzekeraars moeten redden van de ondergang; dit kan ook gebeuren wanneer de kosten voor het uitbetalen van claims hoger zijn dan een onderneming kan dragen.

De waarborg van het klantbelang

Een ander op te lossen knelpunt voor een adequate Europese massaclaimafwikkeling en in wetenschappelijk onderzoek erkend probleem, betreft het lastig kunnen waarborgen van het belang van de gedupeerde consument in de acties van een entiteit die zijn belangen behartigt. Zo blijkt bijvoorbeeld uit wetenschappelijk onderzoek dat een hoog percentage van private claimorganisaties zich niet houdt aan de vereisten van zelfregulering. ${ }^{52}$ Dit betekent dat deze organisaties tot aan het moment van het bewandelen van een collectieve actieof WCAM-procedure acties op de markt kunnen uitvoeren die schadelijk zijn voor hun achterban en de (potentiële) schadeveroorzaker(s). Zij kunnen bijvoorbeeld partijen dwingen om te schikken via imagoschadeacties, of gelden bedoeld voor het bewandelen van een gerechtelijke procedure en verkregen van hun klanten voor eigen doeleinden wegsluizen. Er zou zelfs mogelijk een nieuw op te richten toezichthouder, zoals deze aanwezig is in het Verenigd Koninkrijk, ${ }^{53}$ voor nodig zijn om het klantbelang binnen private claimorganisaties te kunnen waarborgen. ${ }^{54}$ Publiekrechtelijk vormgegeven organisaties die geen winstoogmerk kennen, hebben veel minder prikkels om het klantbelang in hun handelen niet cen-

51. Zie art. 24, 25, 149 en $150 \mathrm{Rv}$

52. T.M.C. Arons, 'Bescherming achterban claimorganisaties en collectief verhaal door toezichthouders', WPNR 2017, afl. 7152, p. 429-440.

53. Dit is de Claims Management Regulation Unit. Een wettelijk haakje voor regulering van claimentiteiten biedt de Compensation Act 2006. Zie: Claims management Regulation Review 2016, p. 15-17.

54. Van Hattum 2017, p. 184-187 en de Claims management Regulation Review 2016 traal te stellen waardoor de Commissie mogelijk ook om deze redenen een overheidsinstantie verkiest boven een private instantie om massaclaims te mogen afwikkelen.

\section{De nadelen van een rol voor een publieke organisatie op het gebied van massaclaim- afwikkeling}

De nadelen van een rol voor een toezichthouder Er kleven zeker ook nadelen aan het toebedelen van een rol aan publiekrechtelijk vormgegeven organen of overheidsorganen in het algemeen. ${ }^{55} \mathrm{Zo}$ heeft een toezichthouder over het algemeen weinig privaatrechtelijke kennis en ervaring in huis om massaclaimproblematiek te kunnen doorgronden en er adequaat op te kunnen reageren. Ook is capaciteit voor het kunnen afwikkelen van een dergelijke claim lastig om te verkrijgen. Een toezichthouder zoals de AFM kent namelijk wel meer dan 150 verschillende toezichtstaken en moet daarom vaak keuzes maken hoe en wanneer op welke mogelijke inbreuk toezicht uit te oefenen. Een massaclaim maakt vanwege zijn complexiteit en grootte het keuzepalet voor het kunnen uitoefenen van alle andere toezichtstaken alleen maar kleiner.

Naast dit meer praktische commentaar bestaat er ook principiële kritiek op een rol voor een toezichthouder bij de afwikkeling van massaclaims geuit door diverse actoren betrokken bij de afwikkeling van Nederlandse massaclaims op de financiële markten. Actieve betrokkenheid van een toezichthouder en daarmee meer toezicht kan, volgens de hierboven genoemde actoren, tot verschillende negatieve effecten in de samenleving leiden. ${ }^{56}$ Bijvoorbeeld tot gemakzuchtige burgers, of een klaagcultuur waarbij toezicht te allen tijde schade dient te voorkomen. In deze tegenwoordig veelvuldig voorkomende cultuur wordt de schuld voor opgelopen schade in eerste instantie bij een toezichthouder geplaatst. Deze had de schade via toezicht moeten voorkomen. En niet, zoals in vroegere tijden meer gangbaar was, bij een consument of in geval van aantonen van causaal verband bij een schadeveroorzaker.

Andere actoren wijzen op negatieve marktwerkingseffecten, aangetoond door wetenschappers, die slechtere eindresultaten (bijvoorbeeld een bereikte schikking) laten zien wanneer toezicht ingrijpt in marktwerkingsprocessen zoals de afwikkeling van zorgplichtclaims. Weer anderen wijzen op het waarborgen van de vrijheid om via procesautonomie het heft bij de afwikkeling van

55. D. Busch, 'Een rol voor de AFM bij afwikkeling van massaschade in de financiële sector?', Ondernemingsrecht 2017/83 (Rechtsorde online); Van Hattum 2017.

56. De in dit artikel beschreven principiële bezwaren op het toebedelen van een bevoegdheid aan een toezichthouder of andere overheidsinstantie (behalve de rechterlijke organisatie of een Ombudsman), zijn ontleend aan Van Hattum 2017, p. 166-168 
zorgplichtclaims in eigen hand te mogen houden. Hierdoor kunnen ze laten zien eigen verantwoordelijkheid te dragen voor het opruimen van door hen zelf veroorzaakte schade bij klanten.

\section{De nadelen van een rol voor een} consumentenvereniging

Het toebedelen van een rol aan een consumentenvereniging zoals de Consumentenbond kent met betrekking tot de inzet van capaciteit een met een toezichthouder vergelijkbaar dilemma. Voor de afwikkeling van een massaclaim is veel capaciteit van de organisatie nodig voor het behartigen van een beperkt deel van de achterban. Die capaciteit (geld, kennis, ervaring en menselijke inzet) gaat dan af van de capaciteit die op andere zaken en de belangen van de rest van de achterban kan worden ingezet. De inzet van third party funding is dan wel essentieel om goed geëquipeerd de strijd aan te kunnen gaan en een massaclaim met een potentiële veroorzaker of veroorzakers ervan te kunnen beslechten. Maar ook dan zal er een team moeten worden opgetuigd dat in staat is zowel via het publiekrecht als het privaatrecht te opereren en zich de kennis van het complexe speelveld van de afwikkeling van massaclaims heeft eigen gemaakt. Dit alles is vaak nog grotendeels afwezig binnen publiekrechtelijk vormgegeven organisaties.

Het toekennen van een belangrijke afwikkelingsrol aan een ombudsman is zeer kwetsbaar gebleken. In het verleden heeft in Nederland de Financiële Ombudsman pogingen gewaagd om zich op het terrein van de afwikkeling van massaclaims te bewegen; dit was weinig succesvol, heeft grote risico's meegebracht en deed zelfs afbreuk aan de autoriteit van het instituut en de ombudsman zelf. Massaclaims blijven vaak zeer complexe problemen waarvoor tijd, geld en de inzet van diverse experts nodig is om ze adequaat op te kunnen lossen. Hiervoor is het van belang om breder te kijken dan naar een oplossing die alleen via de inzichten van (privaatrechtelijke onderlegde) juristen bereikt kan worden. Expertise vanuit het toezicht, de consultancy en informele beinvloedings- c.q. onderhandelingstechnieken en/of alternatieve geschilbeslechting, strekken tot aanbeveling.

\section{Conclusie}

Het Voorstel is een gamechanger

Het Voorstel vermengt zichtbaar de binnen Europa aanwezige verschillende afwikkelingsroutes voor massaclaims, namelijk die van de private en de publieke route. ${ }^{57}$ In Nederland is tot op heden heel duidelijk ingezet op de private afwikkelingsroute waardoor massaclaims

57. Van Hattum 2014. De eerder ontwikkelde Europese wetgeving voor de afwikkeling van massaclaims in het mededingingsrecht heeft als doelstelling ook duidelijk aangegeven om de wisselwerking tussen de publiekrechtelijke en de privaatrechtelijke handhaving van het mededingingsrecht te regelen op een zodanige wijze dat de hoogste doelmatigheid van de mededingingsregels wordt gegarandeerd. Zie: Cauffman 2015, p. 126 veelal worden afgewikkeld via privaatrechtelijk vormgegeven en opererende claimorganisaties, gebruikmakend van de collectieve actiewetgeving inclusief de WCAM. De enige publiekrechtelijke speler in de Nederlandse afwikkeling van massaclaims met betrekking tot gebrekkige producten en dienstverlening aan consumenten is de ACM. ${ }^{58}$ Deze toezichthouder heeft alleen tot op heden nog nooit haar bevoegdheid om massaclaims af te kunnen wikkelen gebruikt. De redenen daarvoor zijn niet openbaar gemaakt, maar waarschijnlijk speelt de vaak hoge capaciteit die moet worden ingezet met bijbehorende kosten een rol. De inzet van deze capaciteit en overige kosten gaat ten koste van andere uit te voeren taken. Ook kan er sprake zijn van een gemis aan kennis en ervaring op het terrein van massaclaims bij een toezichthouder. ${ }^{59}$ Verder bestaat er een hoge drempel om de bevoegdheid toe te passen omdat de toepassing slechts mogelijk is indien de markt zelf niet efficiënt en effectief een oplossing voor een massaclaim kan bereiken. ${ }^{60}$ Dit moment is voor een toezichthouder lastig te bepalen omdat de criteria voor het mogen toepassen van de bevoegdheid niet duidelijk in de wet staan omschreven.

Dit laatste kan veranderen wanneer de huidige inhoud van het voorstel van de Commissie in Nederland dient te worden geimplementeerd. De in Nederlandse wetgeving hiervoor genoemde drempel bestaat namelijk niet in het Voorstel dat op minimumharmonisatie is gebaseerd. De drempel zal daarmee wellicht moeten verdwijnen waardoor een toezichthouder zich eerder met massaclaimafwikkeling kan gaan bemoeien dan nu het geval is in Nederland. Naast een toezichthouder kunnen ook belangenverenigingen zoals de Consumentenbond en een Ombudsman meer invloed krijgen in het speelveld van de afwikkeling van massaclaims in Nederland. Hierdoor dienen de kaarten voor een te bewandelen processtrategie en de vormgeving van financieringsmogelijkheden voor de overige al bestaande spelers in het veld wellicht opnieuw te worden geschud.

Het is verder ook nog de vraag hoe lang het begin dit jaar door Justitie en Veiligheid ingediende wetsvoorstel ter invoering van de ooit ingediende motie-Dijksma na eventuele goedkeuring van de Eerste en Tweede Kamer $^{61}$ stand kan houden. Het wetsvoorstel is namelijk volledig in lijn met de in Nederland jaren geleden gekozen private route waarin de verdiscontering van het algemeen belang in een afwikkelingsresultaat niet is

58. Art. 3:305d BW jo. art. 2.6 Whc.

59. Van Hattum 2017, p. 104-111

60. Kamerstukken I/ 2005/06, 30411, 6, p. 9

61. De goedkeuring van de Eerste en Tweede Kamer is nog geen feit en hangt o.a. ervan af in hoeverre er wordt geluisterd naar het veelvuldig geuite commentaar op het voorstel. Zie hiervoor met name: E. Bauw en S. Voet, 'Van stok achter de deur tot keurslijf? Een eerste verkenning van het wetsvoorstel tot invoering van een collectieve schadevergoedingsactie', NJB 2017, p. 244 e.v.; M. de Vries, 'Voortmodderen met de massaclaims', Advocatenblad 2017, afl. 8, p. 50-53; W.H. van Boom, 'Wetsvoorstel richt zwaar geschut op alle collectieve acties' (een blogbericht) en W.H. van Boom en F. Weber, 'Collectief procederen', WPNR 2017/7145; Van Hattum 2017, p. 86 en I.N. Tzankova, 'Wetsvoorstel collectieve schadevergoedingsactie: een oplossing voor welk probleem ook alweer?', TVP 2017-4, p. 107-119. 
gewaarborgd. Het voorstel blijft uitgaan van de beslechting van een geschil tussen twee of meerdere private procespartijen die onder geen beding kunnen worden gedwongen te schikken of een derde belang in hun beoogde eindresultaat te verankeren. De Richtlijn betreffende schadevorderingen wegens inbreuken op het mededingingsrecht heeft hier geen verandering in aangebracht. De Commissie wenst het algemeen belang wel in een afwikkelingssysteem van massaclaims te waarborgen via de invoering van nieuwe bevoegdheden aan een daarvoor specifiek door de overheid opgerichte of ingestelde entiteit. $\mathrm{Zij}$ wenst de afwikkeling niet alleen of overwegend aan private partijen over te laten.

Dit alles overziend vormt de inhoud van het huidige voorstel van de Europese Commissie zeker een gamechanger in Nederland. Voor andere Europese lidstaten kan dit om vergelijkbare redenen ook een gamechanger worden. Zelfs in Amerika zullen er organisaties zoals advocatenkantoren zijn die hun strategieën en beleid hierop moeten heroverwegen en mogelijk aanpassen om in de toekomst nog te kunnen blijven groeien.

\section{Maar: er zit een adder onder het gras}

In hoeverre de invoering van een groepsvordering daadwerkelijk zal bijdragen aan het door de Commissie beoogde doel van het waarborgen van de rechten van de EU-burger blijft de vraag. Uit wetenschappelijke onderzoeksresultaten blijkt dat het toebedelen van een rol aan een publiekrechtelijke organisatie op het gebied van massaclaimafwikkeling wel degelijk kan bijdragen aan het versterken van de positie van een consument. ${ }^{62}$

Zoals ik in dit artikel heb aangegeven zijn deze organisaties ervoor bedoeld om in hun handelen het algemeen belang te waarborgen en daarmee ook de belangen van de gewone consument. Zij kunnen in het proces van afwikkeling het belang van een gedupeerde consument vooropstellen en ook het algemeen of derde belang wanneer dat aanwezig is goed in een eindresultaat verdisconteren. Maar er zit wel een adder onder het gras. Deze adder is de invloed van staatsbemoeienis op een van oorsprong sterk privaatrechtelijk ontwikkeld terrein: dat van claims. Claims vormen namelijk eigendomsrechten en die zijn grotendeels in beton gegoten.

Voordat het voorstel definitieve vorm gaat krijgen lijkt het mij daarom evident dat er nog vele debatten over zullen plaatsvinden. Deze debatten zullen in de kern waarschijnlijk zijn terug te voeren op de oude tegenstellingen op het gebied van normatieve overwegingen tussen de liberalen en de socialisten. Namelijk: in hoeverre is het wenselijk al dan niet noodzakelijk dat de overheid zich gaat mengen in van oorsprong privaatrechtelijke zaken zoals het afwikkelen van massaschade? En is iedereen vrij om zelf de koers van afwikkeling te mogen bepalen of moet er collectief via inmenging van de Staat een oplossing worden bedacht?

De Commissie kiest voor een duidelijke koers: massaclaims op het gebied van consumentenbelangen zijn niet privaat, maar hebben een publiek karakter. Het publieke karakter moet duidelijker worden erkend in afwikkelingssystemen binnen de EU. Hierdoor mogen, in de ogen van de Commissie, individuele rechten van de burger zoals eigendomsrechten en de vrijheid om individueel de toegangswijze tot het recht te mogen bepalen, worden ingeperkt. De keuze voor een opt-outmodel en het toekennen van een bevoegdheid aan een publieke organisatie om finale sluiting te mogen afdwingen onder procespartijen vormt een bewijs voor deze conclusie.

Maar is de Commissie zich wel bewust van de impact van haar voorstel en de gevaren die hierin schuilen? Een publiekrechtelijke organisatie, hoe onafhankelijk van een ministerie ook vormgegeven, is en blijft namelijk in de praktijk beïnvloedbaar door de politiek; dat moet iedereen bij een nadere invulling van het voorstel van de Commissie goed beseffen. Waarschijnlijk zal dit besef binnen de Nederlandse delegatie in de EU aanwezig zijn gezien de grondslagen van het Nederlands wettelijk kader en de inhoud van dit artikel. Ik ben benieuwd naar de afloop van het wetgevingsproces. Wordt vervolgd! 